prepare for it. Scientists are too busy to undertake historical studies, and literary people can hardly be expected to reeducate themselves along scientific lines. A bridge must be built. The task of unification must be intrusted to specialists, equally well trained as scientists and historians. There is no other way out. Complete courses on the history of science must be organized, and at least a few men must be given the material possibility of devoting themselves entirely to this work of synthesis.

The books of which I have spoken are new tokens, among many, of the irresistible movement which is leading to the organization of these studies and we must be grateful to all those who are helping-either as scholars or as vulgarizers. It remains to be seen which university will take the lead; the others will follow.

George Sarton

\section{INVERTEBRATE PALEONTOLOGY}

IN 1879 Hall described in a Report of the New York State Museum a curious fossil from the Silurian, giving it the name Camarocrinus stellatus. It was a large globose structure, internally divided into several chambers, attached at one end to a stem agreeing with that of the crinoids. Hall surmised that it represented the base of some crinoid species, the other end of the stem, with its calyx, being still unknown. This explanation was generally accepted, but the peculiar chambered bulbous form was supposed to represent a special adaptation for a floating mode of life, the bulb being in fact a float, from which the crinoid hung suspended in the water. In 1904 Dr. R. S. Bassler, of the U. S. National Museum, found an apparently promising locality for Camarocrinus a fow miles north of Cape Girardeau, Mo., along the bluffs of the Mississippi River. This led $\mathrm{Mr}$. Frank Springer in 1912 to send Mr. F. Braun to the locality, with the result of uncovering the most marvelous specimens of crinoids, completely solving the mystery of Camarocrinus, and furnishing the National Museum with a slab about 4 by $5 \frac{1}{2}$ feet, covered with remains of the animals. This slab, now mounted in the hall of invertebrate paleontology, will always remain one of the most striking paleontological specimens in existence, for it shows the animals as they died, probably smothered by a deposit of mud brought by a swift current from some higher level. Mr. Springer has prepared a detailed and beautifully illustrated account of the new materials, and has taken occasion to review all the congeneric species found in America. ${ }^{1}$

It turns out that Camarocrinus is the basal end of a well-known crinoid, described first from Bohemia by Zenker in 1833. Zenker called it Scyphocrinites, and according to the rules of nomenclature this is the proper name, but students of crinoids have chosen to shorten such names, in the present case writing Scyphocrinus. The Missouri slab proves to belong to Zenker's original species, S. elegans, the American specimens agreeing in all respects with those from Bohemia. The basal bulb was not afloat at all, but was embedded in the mud, acting as a root. In its resemblances to and differences from the calyx end it suggests some interesting reflections in connection with the researches of Professor C. M. Child, of Chicago. To what extent is it purely adaptive, and how much of its form and structure depends upon a principle of partial repetition of the fundamental structure of the animal?

Although the Missouri slab represents the Bohemian species, Mr. Springer finds that there are no less than seven other forms of Scyphocrinites (or, as he writes it, Scyphocrinus) in American rocks. S. stellatus is Hall's original Camarocrinus; S. pratteni is a very fine species from Tennessee, described under another generic name by McChesney as early as 1860; S. ulrichi was described by Schuchert as a Camarocrinus; and finally $S$. spinifer, $S$. mutabilis, $S$. pyburnensis and $S$. gibbosus are published as new by Mr. Springer.

The Carboniferous (Pennsylvanian) rocks of Maryland, Pennsylvania, West Virginia and Illinois have in recent years yielded a most interesting assemblage of fossil insects, which

1 Frank Springer, "On the Crinoid genus Scyphocrinus and its Bulbous Root Camarocrinus, Washington, Smithsonian Institution, 1917; 74 pp. and nine plates. 
seem likely to afford important aid in working out the stratigraphy, and also to throw new light on the relationships between the faunæ of the old and new worlds in Carboniferous time. Many of the American species, though described and figured, still await publication. In the meanwhile, it is satisfactory to find that, in spite of the war, the insects of the European coal-measures are being fully described and well figured by Mr. Herbert Bolton, of the Bristol Museum. The apparent poverty of England in fossil insects of Paleozoic age may prove illusory, due merely to lack of interest in their discovery and identification. At all events, Mr. Bolton is making known a number of new types, his latest paper on this subject ${ }^{2}$ containing accounts of new species, and a very fine new genus, for which he unfortunately uses the preoccupied name Palaeomantis. In another paper ${ }^{3} \mathrm{Mr}$. Bolton gives an account of some insects from the coal measures of France, describing among other things the singular new genus Megagnatha, which appears to have long slender jaws, recalling those of the modern Corydalis male. The name Megagnathus has been applied to a genus of beetles, but it is to be hoped that no one will think it necessary to alter the name of Mr. Bolton's genus. Those who propose to change names in zoology, merely because they are thus similar, can hardly understand what confusion would result from the universal application of such a method. We all agree that absolute homonyms can not be permitted to stand, but a difference in the ending of the word is abundantly sufficient to prevent confusion. In connection with the evolution of cockroach types in America and Europe, particular attention must be called to Mr. Bolton's Neomylacris lerichei, which certainly has a strongly American facies. I should call it Promylacris lerichei, referring it to a genus described from Mazon Creek, Illinois.

2 "On some Insects from the British Coal Measures,"' Quart. Jour. Geol. Society, Vol. 72 (1916), pp. 43-62.

8 “"The Mark Stirrup Collection of Fossil Insects from the Coal Measures of Commentary (Allier), Central France,"' Mem. Manchester Lit. and Phil. Society, May 11, 1917.
While the European Paleozoic insects are thus being elucidated, very welcome information reaches us from Australia, of the discovery of a rich fauna of Mesozoic insects. ${ }^{4}$ It appears that the specimens represent a Triassic fauna, and consequently tend to complete our ideas of insect phylogeny, filling in a gap which has hitherto existed in the record. One of the Neuropteroid faunas is referred by $\mathrm{Mr}$. Tillyard to a new order, Protomecoptera, having the surface of the wings finely reticulated. In modern Panorpa traces of the primitive reticulation can be seen in a good oblique light, and it really seems unnecessary to recognize more than a superfamily (Archipanorpoidea).

\section{UNIVERSITY of Colorado}

T. D. A. CockerelL

\section{SPECIAL ARTICLES THE EVOLUTION OF BACTERIA}

Dr. I. J. KuIGLER has recently contributed a paper on "The evolution and relationship of the great groups of bacteria." 1 The conclusions reached are so surprising and so in conflict with commonly held opinions that the contribution is well worthy of careful scrutiny to determine whether or not the premises are reasonable, and the deductions logical. It appears to the writer that in several instances Dr. Kligler has failed to prove his points and that his conclusions, at least when based upon the premises and the reasoning used, are open to serious question.

Probably no fault can be found in the introductory statement that the bacteria are "among the most primitive of living forms." It should be remarked, however, that this does not prove that the present living bacteria are any of them identical with, or even closely related to, the original types of bacteria which appeared upon earth. The next statement can not be accepted quite so readily. The author says:

4 R. J. Tillyard, "Mesozoic Insects of Queensland," Proc. Linn. Soc. New South Wales, July 11, 1917. Also publication 253, Queensland Geological Survey (1916).

1 Journal of Bacteriology, March, 1917. 